This item was submitted to Loughborough's Research Repository by the author.

Items in Figshare are protected by copyright, with all rights reserved, unless otherwise indicated.

\title{
Making democracy legible? Voter registration and the permanent electronic electoral list in Benin
}

PLEASE CITE THE PUBLISHED VERSION

http://dx.doi.org/10.1111/dech.12148

\section{PUBLISHER}

(C) 2015 International Institute of Social Studies. Published by Wiley

\section{VERSION}

AM (Accepted Manuscript)

\section{PUBLISHER STATEMENT}

This work is made available according to the conditions of the Creative Commons Attribution-NonCommercialNoDerivatives 4.0 International (CC BY-NC-ND 4.0) licence. Full details of this licence are available at: https://creativecommons.org/licenses/by-nc-nd/4.0/

\section{LICENCE}

CC BY-NC-ND 4.0

\section{REPOSITORY RECORD}

Piccolino, Giulia. 2015. "Making Democracy Legible? Voter Registration and the Permanent Electronic Electoral List in Benin". Loughborough University. https://hdl.handle.net/2134/22706. 


\title{
Making Democracy Legible? The Politics of Voter Registration and the Experience of the Permanent Electronic Electoral List in Benin
}

\section{Giulia Piccolino}

Accepted Manuscript. The definitive version of this article will appear on Development and Change, 46(1), 2015 (Wiley-Blackwell Press $\mathbb{C}$ )

\begin{abstract}
A core component of the infrastructural power of the modern state is the capacity to make its population 'legible', through the development of accurate registration and identification mechanisms. In discussing the relationship between democratization and state building, little attention has been paid to the electoral process as a technical process. Yet, the introduction of competitive elections presupposes the registration of voters and thus requires the development of the 'legibility' capacities of states. This is particularly evident in sub-Saharan Africa, where democratizing states have been confronted with the weakness of their existing records and forced to develop new mechanisms for registering voters in a reliable manner. This article looks at the experience of the Liste Electorale Permanente Informatisée (the Permanent Electronic Electoral List) in Benin and discusses the potentialities and limits of voter registration as a state-building tool.
\end{abstract}

\section{Acknowledgements?}

This article is part of the project "The economic, social and political consequences of democratic reforms. A quantitative and qualitative comparative analysis (Acronym COD, Grant agreement no.: 262873). Fieldwork in Benin was conducted with the support of the European Union Framework Programme 7, while the Alexander Von Humboldt Foundation is founding my current position. I would like to thank Giovanni Carbone and the Department of Political and Social Sciences of the University of Milan for having given me the opportunity to take part in the COD project. I would also like to thank, among others, Francis Akindès and Christian Agossou, as well as the Socioanthropology department of the Universite de Abomey Calavy and the Laboratoire d'Etudes et de Recherche sur les Dynamiques Sociales et le Développement Local (Lasdel), for helping me with the practical aspects of my fieldwork. Keith Breckenridge, Azizou Chabi Imorou, Matthias Hounkpe, Julien Morency-Laflamme and Sonja Theron, as well as the anonymous referees of Development \& Change, read previous versions of this article and provided useful comments. 


\section{INTRODUCTION}

Creating capable and functioning states has always been a major preoccupation of both the science and practice of politics. What is new in our time, however, is that states today are expected to govern effectively but also to respect standards of democratic governance. Elections are a central aspect of democracy and an increasing number of countries have been holding elections in the last twenty years, including some of the poorest and weakest states of the world. Has this trend had any impact on state building? Is a consolidated state a prerequisite for successful democratic elections or might the introduction of democratic elections stimulate the development of state capacity? The relation between elections and state building has been discussed in the academic literature mostly as a problem of reconciling democratization and political stability (Huntington, 2006; Mansfield and Snyder, 1995; Paris, 2004). The impact on state building of the electoral process as a technical process has received very little attention.

In this article, I focus on the relation between the electoral process and a particular aspect of state capacity: the ability to make the state's population 'legible' from an administrative point of view (Scott, 1999). This power is central to the 'infrastructural power' (Mann, 1984) of the modern state and its daily functioning: although many definitions of statehood focus on the monopoly over the use of force, a definitive feature of the modern state is its success in establishing itself as a 'registering organization' (Breckenridge and Szreter, 2012; Diamant, 2001). However, with a few exceptions (e.g. Slater, 2008), most accounts of how states have tried, with different outcomes, to develop modern records, and of the challenges that this enterprise has faced, focus on historical case studies (Diamant, 2001; Loveman, 2005; Pearce, 2001; Ploux, 1999) and do not engage with current challenges, notably that of reconciling state building and democratization.

In this article, I argue that the development of electoral technologies of 'legibility', particularly voter registration, offer an interesting perspective to explore the relation between democracy and state building in contemporary developing countries. On the one hand, the case of voter registration confirms the importance of state capacity as a prerequisite for successful democratization and for the improvement in democratic quality. On the other hand, voter registration processes also show that competitive elections can be seen as a moment of the statebuilding process: by counting and registering those who will be granted the opportunity to vote and by distributing documents to them, voter registration in fact 'creates' citizens and thus contributes to the establishment of a modern state. However, I also contend that the causal link between voter registration and state building is complex and that the effort to develop accurate records can go 
hand in hand with conflict and societal division. I illustrate my point with reference to sub-Saharan Africa, a region of the world that contains, by all accounts, some of the weakest states in the international system. I use as a case study the establishment in 2011 of a new system of voter registration in Benin that aimed at improving the accuracy and safety of the voter roll, the Liste Electorale Permanente Informatisée (LEPI) - the Permanent Electronic Electoral List.

The next section reviews the concept of legibility and examines the relation between legibility and democracy. The subsequent section addresses the problem of legibility and statehood in sub-Saharan Africa, by looking at the political and historical circumstances that are at the root of the challenges faced by current African states. I then review the LEPI process in Benin, paying particular attention to the type of challenges that this process has faced and to the impact of the LEPI on the development of state capacity.

\section{LEGIBILITY, DEMOCRACY AND VOTER REGISTRATION}

The history of modern statehood in the industrialized world is very much a story about the reinforcement of the state, which has gone hand in hand with a 'humanization' of state power. Historical sociologist Michael Mann has famously distinguished two types of state power: 'despotic' and 'infrastructural' power (Mann, 1984, 2008). Despotic power relates to the power of state elites on civil society and the range of policies that state elites can choose. Infrastructural power refers to the capacity of the state to penetrate and centrally coordinate civil society through its infrastructural network. States have used a range of logistic techniques and technologies to secure infrastructural power, such as an appropriate division of labour between the different branches of the administration; literacy; standardization of measures; and development of communication and information networks (Mann, 1984). These techniques are not specific to the state - they might have been pioneered or subsequently adopted by civil society — but they enhance infrastructural power as long as a state is able to employ them to advance its goals. Infrastructural power thus encompasses what is commonly termed bureaucratic effectiveness, but seems also to require a certain capacity to engage with social actors as it is not power on society but through society. Mann argues that many traditional monarchies and empires were strong in despotic power but weak in infrastructural power. Conversely, many modern Western democracies are strong in infrastructural power, but weak in despotic power. When the prism of infrastructural power is adopted, a 'democratic Leviathan' is not a contradiction.

Mann is mainly concerned with the overall incremental expansion of infrastructural power through history, although he acknowledges the fact that some contemporary developing states 
remain weak in terms of infrastructural power (Mann, 2008). He does not discuss in depth a core preoccupation of these states: the opportunities and risks that a context of demise of despotic power (in other words, democratization) offers in terms of gains in infrastructural power. However, Mann's notion of infrastructural power seems to imply a negotiated and contractual relationship between the state and society, opening the possibility that democratic states and welfare states may be better placed to increase infrastructural power than states that are despotic or that are not interested in providing services to their citizens. This point has been remarked upon by scholars of contemporary developing countries. For instance, John Lucas has argued with respect to Nigeria in the late 1980s and early 1990s that the military leadership of the country undermined the state's infrastructural power in its effort to exercise unbounded despotic power (Lucas, 1998).

While many authors have emphasized state building as a process of establishing the monopoly of the use of force on a given territory, an important and often neglected aspect of the state's infrastructural power is its capacity to make 'legible' its territory and population. As James Scott puts it, 'the premodern state was, in many crucial respects, partially blind' (Scott, 1999: 2). For Scott, the development of 'legibility' encompasses 'processes as disparate as the creation of permanent last names, the standardization of weights and measures, the establishment of cadastral surveys and population registers, the invention of freehold tenure, the standardization of language and legal discourse, the design of cities, and the organization of transportation' (ibid.). These are also some of the technologies that Mann (1984) includes in his discussion of infrastructural power. Scott observes that legibility implies the reduction of the complexity of reality (Scott, 1999: 6). He is thus preoccupied with the potential risks that states' efforts at asserting their domination through legibility entail. However, he himself recognizes that, just like Mann's concept of infrastructural power, legibility tools are normatively neutral and are essential to the enjoyment of the benefits that the modern state provides (ibid.: 4).

Legibility is constitutive of citizenship: in order to be fully recognized as citizens, people inhabiting the territory over which the state claims jurisdiction must be visible to the state authorities and be granted official documents. Nevertheless, the process of registering individual identity produces 'some form of dialectical tension between the legalistic fiction or convention of fixed, defined or stated identities, and the more messy social and cultural reality' (Breckenridge and Szreter, 2012: 20). Moreover, citizens may perceive even seemingly innocuous administrative innovations, such as the introduction of censuses (Pearce, 2001; Ploux, 1999), civil registration (Loveman, 2005) or marriage registration (Diamant, 2001), as suspect or intrusive practices, and resist them through open revolts or silent non-compliance. Frequently, the association of these practices with taxation and military conscription has been seen as the main motivation for their rejection. However, other reasons, such as cultural and spiritual beliefs, general mistrust of state 
authorities or rejection of foreign rule have also played a role (Diamant, 2001; Loveman, 2005; Redding, 2000).

'Legibility' is also a necessary prerequisite to the holding of democratic elections. In discussing the relation between democracy and state building, the electoral process in itself has not received much attention. However, elections are first of all 'a tremendous organizational challenge' (Bierschenk, 2009: 354). They not only entail the organization of 'a chain of procedures to take place within the short span of 12 hours at several thousand locations scattered throughout a national territory' (ibid.) but also imply that a reliable database of people eligible to vote exists and that these people carry documents that may certify their status as electors.

Like censuses and other governmental statistics, electoral registration is not a 'neutral' technology but it is influenced by a host of historical, cultural and political factors (Evrensel, 2010; Yard, 2011). The mechanisms employed by both old and new democracies and developed and developing countries for registering electors are extremely varied. Voter registration can be compulsory or voluntary, it can be based on a permanent list continuously updated or on a periodic list. In several old democracies, registries and documents existing for other purposes, particularly civil registries and identity cards, are used for identifying electors. Countries that do not have a reliable civil registry, as well as some other old democracies, opt instead for a list specifically compiled for electoral purposes.

While the role of the legibility capacity of the state as a precondition for successful voter registration and thus free and fair elections is quite self-evident, a distinct question arises, related to the possibility that voter registration may also act as a stimulus for the development of state capacity (Carbone, 2013). This hypothesis has been put forward by East Asia scholar Dan Slater (2008). Slater in fact focuses on legibility and observes that the most common mechanisms for ensuring that a state can 'read' its population - civil registration systems and censuses - were introduced in many colonial and post-colonial states in relation to goals that were unpopular. Yet, voter registration is a completely different matter. As it grants the right to express oneself in national elections and confers the status of citizens, voter registration has many more opportunities to elicit spontaneous compliance. Once secured, voter registration may have potential spill-over effects on other aspects of administrative capacity.

Slater brings as evidence to his argument the case of the elections organized by the Suharto regime in Indonesia in 1971. He admits that these elections were not strictly speaking democratic, yet he argues that they satisfied the conditions of being competitive and intensely fought, as upon their success depended the survival of the New Order regime. Slater argues that these elections had a major impact on Indonesian statehood and he makes a plausible case that the fact that the Indonesian regime was able to launch many successful interventionist policies in subsequent years 
may be causally linked with its voter registration performance. Slater does not make bold causal claims but argues that this case highlights a potential mechanism through which competitive elections may (but not necessarily will) foster state consolidation (Slater, 2008: 265).

Slater's argument is complemented by other evidence that points to a close relation between the development of registration systems and democracy. Breckenridge and Szreter (2012: 16) observe that 'large systems of registration, whether of people or of things, tend to work only when they provide an obvious benefit to the people being targeted'. They argue that, unlike enumeration and census-like activities, which are mostly 'unilateral interventions by governmental agencies', registration is 'a much more bilateral process, in which the aims and interests of the person being registered may play a significant role' (ibid.: 19). In this sense, democratic states can be both more interested and better suited at establishing and maintaining population registers: a democratic Leviathan may also be a 'registering Leviathan'.

\section{LEGIBILITY IN SUB-SAHARAN AFRICA}

Although many Western and some non-Western states have successfully become 'registering organizations' (Diamant, 2001: 447), many post-colonial states are still partially blind. This is particularly true for the African continent. The incapacity of African institutions to collect reliable data on key aspects of socio-economic life (Jerven, 2013) has been called an 'African statistical tragedy' (Devarajan, 2013). However, the faultiness of vital statistics is a less discussed but even more significant aspect of the African state's 'blindness' (Setel et al., 2007). Although there are important country variations, estimates provide a picture of general failure of birth registration systems in sub-Saharan Africa. According to UN data, with the exception of Mauritius, Cape Verde and other small insular states, all countries in the region are below the 90 per cent threshold that the United Nations system considers indicative of an effective birth registration system. South Africa, Cameroon and Gabon approach the 90 per cent threshold but the rate of birth registration in some other countries, such as the Democratic Republic of the Congo (DRC) and the Central African Republic in Central Africa, or Liberia and Guinea in West Africa, is estimated at less than 50 per cent: see Table A1 in the Appendix for a full listing.

It is not possible to understand the weaknesses of African state records without considering the history and evolution of the African state system. With a few exceptions, pre-colonial Africa did not witness the emergence of Europe-like nation states, not least because of territorial and demographic conditions particularly unfavourable to state building (Herbst, 2000). Most current 
African states are not the descendants of pre-colonial polities but of the colonial states created by European occupants. Most scholars track the current weaknesses of the African state system back to colonial origins. Jeffrey Herbst, for instance, contends that the colonial state had uneven and partial control over its nominal territory and that post-colonial states have inherited such weakness (Herbst, 2000). Pierre Englebert points out the illegitimate nature of the colonial state as an instrument of foreign rule and argues that this exogenous nature of African statehood is at the roots of neopatrimonialism and corruption in modern-day Africa (Englebert, 2000). Jean Pierre Olivier de Sardan puts forward the hypothesis that the pathologies of current West African bureaucracies can be traced back to the characteristics of the colonial administration (Olivier de Sardan, 2004).

Using Mann's distinction between infrastructural and despotic power, it can be said that the colonial state was strong in the latter but weak in the former (Herbst, 2000). There were several reasons why colonialists, with a few exceptions, were generally poor state builders. Colonialists were accountable to taxpayers in the metropole, rather than to the colonized population. At least until the last years of occupation, when concerns about the welfare of the colonial population started to be raised, colonial administrations tried to establish political control on the cheap (Cooper, 2002). They seldom engaged in the wide range of policy-making and regulatory tasks performed by their contemporary European counterparts.

The nature of colonialism also impacted on the way the colonial state attempted to make its population legible. Colonial administrations carried out censuses and established vital statistics. However, these innovations had limited and often unpopular objectives, such as the imposition of poll taxes (Redding, 2000) and the recruitment of adult men for military service and forced labour. Not surprisingly, these attempts were frequently resisted by the population (Fetter, 1987). As for most of the colonial period the colonial administration did not regard its people as citizens, establishing their individual identity was not paramount. When efforts to create a civil registry were made, such as in the French colonies, they failed when confronted with the contradictions of the colonial doctrine of assimilation (Cooper, 2012).

The post-colonial regimes that ruled African states until the end of the Cold War have done little to improve the capacity of the state to make its population legible. In fact, just like the colonial states, most post-colonial African states were 'lame Leviathans': highly autocratic and personalistic in their mode of governance but weak in securing the monopoly of violence and implementing their policies. Most states kept the colonial systems of vital registration without engaging in significant attempts at improving them. Partly in response to the exhaustion of Cold War patronage and partly because of the reaction of donors and citizens to these shortcomings of governance, since the end of the Cold War, African post-colonial states have been subjected to internal and external pressures to democratize (Bratton and van de Walle, 1997). Although only a minority of contemporary African 
states can be considered fully fledged democracies, most have introduced some features of a democratic system, such as multi-party rule and competitive elections.

Democratization has been accompanied by a strong expectation that competitive elections may improve governance and state effectiveness. However, the general contention is that this has happened only to a limited extent (Bayart, 2000; Bierschenk, 2009; Chabal and Daloz, 1999; van de Walle, 2002). Several possible explanations for this have been advanced, such as the diffusion of electoral clientelism (Lindberg, 2003), the rarity of strong party organizations (Bleck and van de Walle, 2011) and the impact of external rents on the accountability of elected governments (Moss et al., 2006). A more optimistic picture has been provided by Michael Bratton and Eric Chang, who have argued that democracy, by enhancing the legitimacy of the state, is gradually favouring the establishment of a state based on the rule of law in Africa (Bratton and Chang, 2006).

In the framework of this debate, the relation between the electoral process and the improvement of state capacity has received little attention. With the introduction of competitive elections, however, many African states have been obliged to confront the fact that their existing state records were too unreliable to provide an accurate voter list and have been forced to improve their capacities to register and identify their population. Indeed, Africa has become the theatre of a series of experiments, often encouraged by development agencies and donors, aimed at improving the transparency of the electoral system by making voter registration more reliable (Evrensel, 2010; Yard, 2011). On the one hand, these experiments have involved the move from local polling-station based lists to centralized lists, supposed to facilitate the identification of citizens and prevent multiple registration. On the other hand, many states have tried to make voter registration more reliable and manageable by introducing technological innovations, notably biometric registration systems. It remains debatable if these innovations are allowing African states to 'leapfrog' or if they risk creating additional problems (Breckenridge, 2010; Breckenridge and Szreter, 2012; Gelb and Clark, 2013; Gelb and Decker, 2012). Breckenridge and Szreter (2012: 2) argue that, by sparing these states the need to invest in the type of identification work that entails the creation of largescale permanent structures, biometric technologies are in fact undermining the possibility that voter registration may result in a durable augmentation of state capacity. Evrensel (2010:2) argues that sophisticated technology 'increases organisational and logistical challenges' and that it 'can be a threat to the acceptance, transparency and security of the system' (ibid.: 3). Biometric identification can address certain problems affecting the voter registration process - notably the risk of double registration - but not others, such as the lack of identification documents and of an accurate civil registry (Piccolino, 2015). Thus, in spite of technological innovations, some form of identification through self-attestation or witness statement remains necessary. Moreover, in many African states, voter registration has turned out to be a controversial, if not the most controversial, aspect of the 
electoral process. As trust between the rulers and the opposition generally continues to be low and as the diffusion of electoral observation makes election-day fraud increasingly difficult, the compilation of the electoral list has often turned into a battlefield.

In the next section I explore the case of the introduction of a new voter registration system — the Liste Electorale Permanente Informatisée (LEPI) — in Benin. Benin is a significant case to explore the relation between democratic elections and 'legibility' as it has a heritage of poor and deficient state institutions, but it has been a pioneer in starting a process of democratization in West Africa. In spite of this, voter registration in Benin has been a contentious process and not all the expected benefits of the LEPI have materialized.

\section{VOTER REGISTRATION IN BENIN}

Although Benin is a small country of about 9 million inhabitants, it has a strong symbolic importance in the history of French-speaking Africa. In 1990, following widespread protests against the economically and ideologically bankrupt Marxist-Leninist regime of Mathieu Kérékou, Benin was the first country among the former French African colonies to initiate a process of democratization. Its formula of convening a Conférence Nationale (National Conference) for managing the transition to democracy has been regarded as an important innovation for coping with the uncertainties of regime change and proved an inspiration for several other French-speaking African countries (Allen, 1992; Banégas, 2003; Gisselquist, 2008; Heilbrunn, 1993)

Benin was considered an unlikely candidate for democratization, given its extremely weak economy and deficient state institutions (Allen, 1992; Bierschenk, 2009; Gisselquist, 2008; Igue and Soulé, 1992). There is little doubt that Benin's democracy is plagued by electoral clientelism (Wantchekon, 2003), extensive corruption (Bako-Arifari, 2001; Blundo and Olivier de Sardan, 2006) and a heritage of weak institutional capacities (Bierschenk, 2009; Olivier de Sardan, 2004).

Overall, however, Benin satisfies the minimal requirements to be considered a democracy and it is regularly rated a 'free' country by the most common international indexes.

In spite of its relatively early democratization, until recently Benin relied on an unsophisticated and quite dubious mechanism of voter registration for its elections. Before every election, citizens were asked to register at polling sites. Given that the lists were manual and nonconsolidated, it was easy to manipulate the system and register at multiple sites. The risk was increased due to the fact that most voters could not present identity documents and were enrolled through testimony of their peers. 
In Benin, national identity cards are released only by the corps préfectoral, which represents the central state at the local level, and just a small minority of Beninese citizens hold them. The 2003 decentralization reform eliminated the sous-préfectures but did not grant to Beninese communes the prerogatives to deliver national IDs, making access to them even more difficult, since citizens have now to travel to the seats of the less numerous preféctures to obtain their documents. Birth certificates, which are managed by the communes, are more common, but an important share of the population is still not registered at birth. Benin's civil registration system was created at the time of colonialism and was reformed only by the new family code in 2002 (Republic of Benin, 2002). ${ }^{1}$ According to the estimates of the Demographic and Health Survey, in 2001, 26 per cent of children younger than five were not registered. In 2006 the share had raised to 31 per cent (INSAE, 2002, 2007), probably due to problems of transition to the new civil registration system. According to Beninese law, a citizen who does not have a birth certificate can ask for one to be delivered by the tribunals, but the procedure is long and cumbersome. As in most other West African countries, the challenge of developing reliable state records is augmented by the fact that Benin has a relatively low population density and most of its citizens live in villages and small towns in the countryside.

\section{The LEPI Process}

While the process that led to the adoption of the LEPI only started during President Yayi Boni's first term (2006-11), the adoption of a more secure voter list had been on the agenda for a long time. In presidential elections in 2001, when the old autocrat Mathieu Kérékou took the lead during the first round, his rival Nicéphore Soglo boycotted the second round claiming that fraud had taken place. Following this episode, which highlighted the fragilities of Benin's electoral system, Soglo's party, the Rénaissance du Bénin (RB), started advocating the creation of a more reliable list. ${ }^{2}$ Between 1998 and 2004 the Beninese government commissioned a series of feasibility studies about the LEPI from development agencies and state institutions, but without any concrete follow up (Sessou et al., 2009). The majority of the Beninese political class was wary of changing the voter registration system. The feeling of Benin's political parties that they benefitted from the looseness

\footnotetext{
${ }^{1}$ Interview with former Beninese civil servant and consultant on civil registration issues, Cotonou (5 April 2013); Interview with officer of the Beninese Ministry of Interior, Cotonou (7 April 2013).

${ }^{2}$ Interview with Member of Parliament, Cotonou (1 June 2013).
} 
of the existing system was largely illusory, as electoral irregularities did not favour any particular political group, ${ }^{3}$ but constituted a powerful obstacle to changing it.

In 2006, as part of its reformist ambitions, the new Yayi Boni administration included the creation of a LEPI in its Strategic Orientations for the Development of Benin and began discussions with international donors with a view to obtaining funding for its realization. These discussions led to the publication in 2009 of a feasibility study, carried out by the United Nations Development Programme and European Union (UNDP-EU) joint task force on electoral assistance, which presented for the first time the main elements of the procedure that had eventually to be adopted for the elaboration of the LEPI (Sessou et al., 2009). The envisaged process aimed at creating the LEPI from scratch, through the preliminary execution of a Recensement Electoral National Approfondi (National Extensive Electoral Census, RENA). The execution of the RENA included two phases, while the registration of voters strictly speaking represented a third phase. At first an electoral cartography, detailing the distribution of dwellings over the territory, had to be established for the whole country. The second phase involved a census of Beninese citizens, including minors above the age of eight, in their dwellings by census agents. The biometric registration of electors at chosen sites occurred as a third phase and, unlike the RENA, had a voluntary and non-compulsory character. After processing the registered data, a voter card, which also contained the biometric data, would be delivered to those citizens who had registered.

While the LEPI process was waiting to be launched, the government initiated the Recensement Administratif à Vocation Etat Civil (RAVEC, Administrative Census aiming at Civil Registration), which aimed at providing birth certificates for Beninese citizens who had never held them and at creating an electronic database of people owning a birth certificate. The RAVEC process, which was supposed to prepare the ground for the LEPI, had mixed results (Sessou et al., 2009). It secured the delivery of 2,185,000 birth certificates, but it had to be interrupted due to lack of funding. Moreover, the second phase of RAVEC, the administrative census, could not be executed. The Constitutional Court ruled that this phase was unconstitutional because of procedural issues. This decision limited the possibilities of establishing synergies between RAVEC and the electoral census.

While civil society organizations, grouped in the Fors LEPI coalition, were pushing for the adoption of the LEPI, the commitment of the political classes remained ambivalent. Eventually a law on the adoption of the LEPI was passed in 2009 (Republic of Benin, 2009) and the process that was to lead to the new voter roll was set in motion. Two institutions were created for managing the LEPI process: a political body in charge of the overall supervision, the Commission Politique de

\footnotetext{
${ }^{3}$ Interview with Beninese consultant on governance and democracy issues, Cotonou (21 March 2013); Interview with Beninese political analyst and consultant, Cotonou (15 May 2013).
} 
Supervision de la LEPI (CPS-LEPI), and a technical agency in charge of the execution, the Mission Indépendante de Recensement Electoral National Approfondi (MIRENA). Most of the costs of the project were financed through the Projet d'Appui à la Réalisation de la LEPI (PAREL, Project Supporting the Establishment of the LEPI). The PAREL basket fund was managed by UNDP, which also provided external technical expertise. The government of Benin covered 38.2 per cent of the PAREL budget, while the remaining 61.8 per cent came from donors. The initial budget amounted to US\$ 36,836,366 but the costs gradually increased, reaching US\$ 51,704,804 in March 2011. The purchase of biometric kits represented by far the most expensive component of the project, totalling US\$ 12,950,660 (Assoukpe, 2011: 35). The bulk of external funding was provided by the EU, whose final contribution amounted to about 24.8 per cent of the total budget. Smaller contributions came from the Netherlands (8.93 per cent), Denmark (6.89 per cent), Belgium (5.9 per cent), Switzerland (3.93 per cent) and other donors (ibid.: 33-34). While most personnel in charge of the LEPI process were recruited by the CPS and the MIRENA, the PAREL project also included a small but potentially influential group of international experts in charge of technical assistance. A certain number of local personnel were also recruited directly by the PAREL project as United Nations Volunteers (ibid.: 21-22).

In spite of the almost unanimous vote in favour of the LEPI law, the National Assembly remained divided on the matter. Yayi Boni's Forces Cauris pour un Bénin Emergeant (FCBE) did not hold an absolute majority in the National Assembly. The main opposition parties were divided over the issue of the LEPI but voted together in order not to break the anti-Yayi Boni front. ${ }^{4}$ However, problems re-ignited when the issue of control over the process emerged. Both the CPS and the MIRENA had decentralized structures at the level of the communes. In practice, nominations to the CPS both at the national and local level turned into a battlefield. Political parties also tried to place their followers in the supposedly apolitical MIRENA, which created tensions with the technicians recruited into the organization. ${ }^{5}$

The RENA met with a series of difficulties. During the electoral cartography stage, thirtynine new villages not present on the official maps were discovered. The differences between the official and unofficial names of some other villages also created confusion. ${ }^{6}$ In some areas, the delimitations of the Zones de Dénombrement Electoral (ZED, Electoral Enumeration Zones) posed problems, because of the conflicting interests of local elected representatives. ${ }^{7}$ A more widespread problem, which emerged during the door-to-door census, was the inability of a large number of

\footnotetext{
${ }^{4}$ Interview with Member of Parliament, Cotonou, 1 June 2013.

${ }^{5}$ Interview with former MIRENA local officer, Cotonou (9 March 2013); Interview with MIRENA local officers, Abomey-Calavy (17 April 2013).

${ }^{6}$ Interview with UNDP officer, Cotonou (25 March 2013).

${ }^{7}$ Interview with MIRENA local officers, Abomey-Calavy (17 April 2013).
} 
citizens to present any identification documents: $2,215,859$ out of 7,505,796 citizens aged eight and over (the census target population) were registered on their own declaration or the testimony of the family head (Sangaré, 2012). While, according to the 2009 law, the dossiers of these citizens should have been subjected to a tribunal's judgment in order for them to be able to enrol as electors, this proved impossible in practice.

The main difficulties stemmed, however, from the growing mistrust between the presidential majority and the opposition (Olihide and Alladatin, 2012). Disagreements culminated in a vote of no-confidence and the subsequent forced resignation of the president of the CPS, RB member Epiphane Quenum in March 2010. Quenum was accused by the MIRENA of being technically incompetent and of having poorly managed the process. ${ }^{8}$ Quenum's successor, Nassirou Bako Arifari, a member of the G13 opposition group, was elected unanimously but, after his appointment, was the subject of constant criticism by the rest of the opposition. He eventually switched to the presidential coalition, further fuelling suspicions against him.

The opposition was asking for a revision of the electoral cartography before moving on to the electoral census, while the presidential coalition was strongly opposed to this, believing that it would delay the process and may prevent the LEPI from being ready for the 2011 elections.

External donors were also supporting the 2011 deadline, as they needed to have a ready and usable LEPI in order to justify the investment made. ${ }^{9}$ As a compromise, a Working Group was created to evaluate the cartography and to propose adjustments that could be carried out simultaneously with the door-to-door census, but the opposition later complained that its recommendations had been insufficiently taken into account. Difficulties between the government coalition and the opposition continued and reached a new peak in April 2010 with the resignation of the opposition MPs elected within the CPS, with the aim of paralysing the CPS. In August, the opposition-dominated National Assembly passed a regulation that called for a provisional list to be used in the 2011 elections, instead of the LEPI.

Although the opposition later denied inviting its supporters to boycott the door-to-door census, its leaders' constant criticism of the LEPI was interpreted in this way in some opposition strongholds and there were cases of census agents chased out of houses occupied by opponents and even physically attacked. ${ }^{10}$ However, the attitude of the opposition changed when the Constitutional Court ruled in favour of the employment of the LEPI in the 2011 presidential elections. Opposition parties realized that, if their followers boycotted the census, this risked putting them at a disadvantage at the moment of the vote. The opposition was particularly concerned about the fact

\footnotetext{
${ }^{8}$ Interview with MIRENA local officers, Abomey-Calavy (17 April 2013).

${ }^{9}$ Interview with civil society representative, Cotonou (13 March 2013).

${ }^{10}$ Confidential communication.
} 
that compulsory registration during the RENA was a necessary precondition to the subsequent biometric enrolment. It pushed for the adoption of a law that authorized, a few days ahead of the election, the CPS, MIRENA and the Commission Electorale Nationale Autonome (CENA) to take extraordinary measures 'with the aim of ensuring and facilitating the exercise of their constitutional voting right by the citizens in the voting age' (Sangaré, 2012: 9-10). Thus, citizens excluded from the census were granted five days to participate in the biometric enrolment.

The enrolment phase was by far the most expensive part of the LEPI process, due to the cost of the biometric kits, delivered by the Dutch enterprise Gemalto. Given Benin's tropical climate and the frequent interruptions in power supply even in the capital, breakdowns in the equipment were frequent (Assoukpe, 2011: 75). During the consolidation of the data technical difficulties resulted in the creation of artificial doubles (Sangaré, 2012), although these could be eliminated subsequently, when the biometric data were processed. Eventually, 4,483,420 voter cards were delivered to citizens aged twelve and over, representing 77.73 per cent of the correspondent population registered by the RENA (ibid.).

Although the LEPI was ultimately employed in the 2011 presidential and legislative elections, this did not mean the end of the controversy surrounding it. Moreover, Yayi Boni's decisive victory, both in the presidential elections, where he was able to get elected in the first round with 53.17 per cent of the votes, and in the subsequent legislative elections, where he obtained a net majority of seats at the National Assembly, contributed to re-igniting the debate, with the opposition continuing to insist that the list should no longer be used (Olihide and Alladatin, 2012).

The controversial character of the LEPI among the Beninese political class contrasted with the fairly positive evaluation of the process by the external partners and observers. The Organisation Internationale de la Francophonie (OIF), requested to carry out an independent evaluation of the LEPI, estimated the coverage of the list with respect to the voter population (aged eighteen and above) at 83 per cent, a respectable rate considering that the process was noncompulsory (Sangaré, 2012). By comparing the LEPI database with other demographic data, the OIF identified a series of weaknesses, such as the number of people registered in the RENA without documents or the distortions in the distribution of the age groups, with an over-estimation of the population aged twelve years old (the minimum age for biometric enrolment) and aged eighteen years old (the minimum age for voting). Nevertheless, it claimed that the list represented a net improvement over the previous voting registration system and found no evidence for the hypothesis of a deliberate manipulation of the list by the power holders or for the exclusion of a considerable share of the population due to massive boycott. 
Ultimately, the main problem with the LEPI seemed to lie more in the inability of the Beninese political class and of the external donors to create consensus around the list than in any fatal flaw with the list itself. As time has passed since the 2011 elections there has been a general recognition that the list is usable but needs to be improved and updated, particularly in order to be employed in local elections (Olihide and Alladatin, 2012). New bodies have been created for the processing and updating of the data - the Conseil d'Orientation et de Supervision (COS, Supervision and Orientation Council), which is to some extent the successor of the CPS, and the Agence Nationale de Traitement (ANT, National Agency for Data Management), whose mandate mirrors the MIRENA but with the expectation that it will become a permanent institution (Republic of Benin, 2012). The nomination of members to these two institutions did not result in any major political tension, fostering the hope that some of the expected additional benefits of the LEPI project, such as the possibility of transforming the electoral card into an identity card, could materialize (COS-LEPI, 2014). However, new tensions have emerged following a misconceived attempt of Yayi Boni to amend Benin's Constitution in July 2013 and the opposition and civil society's discontent with his increasingly personalistic style of rule (Banégas, 2014). Thus, the revision process, which should have concluded by the end of June 2014, has continued to experience delays and political and financial difficulties (COS-LEPI, 2014), and the future of the LEPI remains uncertain.

\section{The LEPI and State Building}

Establishing a state administration that is able to 'read' its citizens constitutes a democratic requirement and an important challenge for weak and poor countries like Benin. Contemporary states can pick from a range of 'technologies of legibility' that is larger than that available to historical modernizing states, as well from external financial and technical resources which were previously unavailable.

Slater's hypothesis that voter registration will be less controversial than other forms of state interventions and thus more likely to work as an initial trigger for state building, however, does not seem at first to be confirmed by the case of Benin. The Beninese political class, perhaps not surprisingly, saw the LEPI process not as a neutral technical exercise, but as a political issue generating winners and losers. Voter registration has been a controversial process all along and, although most of the opposition to the LEPI has concentrated at the level of state elites, it has also partially spilled over to the general population. 
The heightened debate generated by the LEPI is surprising given that Benin had long held elections with an unreliable voter registration system. Indeed, one of the expectations of the external backers of the process was that the introduction of a more reliable list would make elections smoother and less affected by possible protests. However, by 'fixing' once and for all the identity of the electors, in contrast to the ad hoc manual lists previously employed in Benin, the LEPI has reduced the opportunities for flexibility and informal bargaining. Weak identity systems 'allow space for familial relationships and bureaucratic discretion to offer loopholes and informal identification to the undocumented' (Gelb and Clark, 2013: 15). On the other hand 'formalizing identity can eliminate this grey area and lead to a stronger division between "insiders" and “outsiders", particularly when citizenship and its associated rights are at stake' (ibid.).

In spite of the LEPI controversy, the boycott of the process at the level of the general population remained limited, as the list coverage demonstrates. Moreover, as all Beninese political actors were forced to acknowledge that anyone who was excluded from the LEPI would not be able to vote for them, they eventually began to encourage their supporters to enrol as electors. The compelling logic of voter registration has thus imposed itself and the process has reached a reasonable level of inclusivity. This conclusion would have been unlikely for other forms of state intervention that may have been perceived - not just by a section of the political elite but by the population at large - as harmful, for instance registration for taxation. This offers support for Slater's observation that voter registration is a type of state intervention that has the potential to elicit spontaneous compliance.

A distinct issue is whether we can speak of a virtuous circle and whether voter registration may have stimulated state capacity and generated a 'spill-over' effect in other policy domains. The LEPI has been heralded at times by the Beninese government and by its international partners as a precious resource for improving state interventions. Notably, the data gathered during the RENA and the biometric enrolment have been presented as a tool for improving the civil registration system, reinforcing development planning, solving land disputes, facilitating police and judicial enquiries, enabling the production of safer administrative documents and so on (Assoukpé, 2011: 94-95). One popular spill-over argument, which has been used to encourage citizens to participate in the biometric enrolment, has been the possible transformation of the voter card into a generally accepted identity document.

However, a series of problems has arisen. The first has been highlighted by the OIF evaluation of the LEPI: while acknowledging the usefulness of the LEPI data, the OIF mission has observed that the information gathered during the RENA and the biometric enrolment could not automatically be employed for other purposes and could not be fed into the civil registration system without undergoing a process of revision. This is because a number of citizens have been registered 
on testimony only, and because the particular purpose of electoral registration has introduced distortions in the declared ages (Sangaré, 2012: 42).

A second problem concerns the impact of the politicization of the LEPI process. One of the first consequences of the mistrust within the Beninese political class was the decision to create ad hoc structures for carrying out the LEPI process. From an institutional point of view, the Commission Electorale Nationale Indépendente (CENA) and the Institut National de Statistique et de l'Analyse Economique (INSAE) were marginalized (Olihide and Alladatin, 2012), although some former INSAE staff were recruited to the MIRENA on an individual basis. This means that, although the LEPI project has mobilized and trained a considerable number of personnel (Assoukpé, 2011: 32), it has not left a robust 'capacity legacy' behind. This may be changing with the creation of the COS and the ANT, which have recruited some former CPS and MIRENA officers and which are supposed to have a long-term mandate. Similarly, the potential application of the LEPI data for non-electoral purposes was seen as problematic due to the amount of controversy that the list generated; weather the ongoing revision of the list will solve this problem remains to be seen.

The relative insulation of the LEPI from other processes supposed to reinforce the legibility capacities of the state, notably civil registration reform, constitutes another problem. The amount of resources poured into the LEPI contrasts sharply with the limited attention paid by Beninese policy makers and international donors to other issues, notably the reform of civil registration. In fact, because of this, the LEPI process has been regarded with hostility by some civil registration officers, who feel that their domain offered opportunities for a real long-term investment in state capacities, while the LEPI represented a waste of energy and funding with no guarantee of creating a sustainable system. ${ }^{11}$ They point out that in spite of the adjective 'permanent' contained in the name, the list has no in-built mechanism for ensuring automatic updates. However, it should not be forgotten that the LEPI has stimulated a debate over the flaws in civil registration: the RAVEC process would probably not have been launched without the perspective of voter registration. The fact that a reorganization of the Ministry of Interior, intended to give more autonomy and power to the civil registration directorate, is taking place in the aftermath of LEPI, does not seem a coincidence.

A fourth problem concerns the role of external donors and externally imported technology. While Slater's case study presents an example of voter registration designed and carried out entirely by the national government, in the case of Benin external expertise has driven many aspects of the process, from its design to the funding and the choice and provision of technology. This reliance on

\footnotetext{
${ }^{11}$ Interview with former Beninese civil servant and consultant on civil registration issues, Cotonou (5 April 2013); Interview with officer of the Beninese Ministry of Interior, Cotonou (7 April 2013).
} 
external resources and expertise to carry out the LEPI project does not necessarily compromise its objectives: Loveman (2005) suggests that initial dependence on non-state resources has often been necessary for the state's 'primitive accumulation' of symbolic power. However, in contrast with historical cases of cooptation of non-state institutions, in which the balance of power eventually shifted to the side of the state, Benin's relationship with donors has remained shaped by subordination and dependency. Moreover, although donors gave some thought to the sustainability and long-term impact of the LEPI process on state capacity, they mainly saw the LEPI as an instrument for reinforcing the democratic process and defusing political tensions. Much of their attention was concentrated on ensuring that the list was ready and could be used in the 2011 elections. During the most tense phases of the LEPI process, donors and UNDP technical assistants were occasionally accused of interfering too much and of being too close to the Yayi Boni regime. ${ }^{12}$

Donors also encouraged the use of biometric technology provided by a foreign firm. In Benin, the use of biometric technology, while facilitating the elimination of double registrations from the list, has involved significant costs. It also created new problems, as the lack of infrastructure and power supply made the use of biometrics particularly challenging for enrolment agents. In addition, the technology was perceived as a 'black box' by non-technicians and contributed to the fears that the government coalition was trying to manipulate the process; in addition,

\section{CONCLUSION}

Administrative 'legibility' constitutes one of the key aspects of the infrastructural power of the modern state. But administrative legibility, expressed through voter registration and identification, is also a precondition for successful elections. An increasing number of countries around the world have experienced some degree of political opening and have held elections in the last two decades. It thus seems appropriate to wonder if administrative weaknesses have jeopardized elections or if, on the other hand, the electoral process, particularly its voter registration component, has stimulated the development of state capacity. This question is particularly salient in Africa, where competitive elections have multiplied in the last twenty years but where states start from a very low level of capacities and where existing mechanisms for registering and identifying citizens are particularly flawed.

\footnotetext{
${ }^{12}$ Interviews with civil society representatives, Cotonou (13 March 2013 and 18 March 2013).
} 
Theoretical speculation and historical research suggest that there may be a link between democracy and elections on the one hand and successful registration mechanisms on the other. Identification is intimately linked to citizenship. To be successful, it requires the collaboration of the citizens and their perception that they are obtaining some tangible benefit. Voter registration appears to be particularly appropriate for eliciting compliance, as its direct association with citizenship and voting rights makes registering for elections appealing to the population. In some instances, such as the Indonesian case reported by Dan Slater, voter registration may be the spark that triggers a wider process of development of state capacities.

In Africa, the disadvantage of authoritarianism with respect to the development of 'legibility' seems evident, as neither colonial states nor the authoritarian single-party regimes of the post-independence period appear to have done much to make their populations 'legible'. Although the former introduced censuses and civil registration, their objectives were limited and the mechanisms remained rudimentary. With the advent of democratization, however, the 'illegibility' of the voter population has become a major political issue.

Benin is an example of an African country that, having experienced a fairly successful democratization process, has struggled to make its voter registration system more reliable. The launch of the LEPI has been a major exercise in 'legibility', entailing both the mapping of the state's territory and the registration of a large share of the Beninese population. It has resulted in many Beninese citizens possessing an official document for the first time. However, the process has entailed a considerable amount of controversy and hopes of a 'spill-over' of administrative capacity to non-electoral domains may not fully materialize.

The case of Benin case suggests that the effort at fixing, once and for all, the identity of the electors, easily induces political tensions. To some extent these tensions may be considered an unavoidable component of the state-building process. In the case of Benin, they were also exacerbated by the absence of a climate of trust and by the over-politicization of Benin's state system. Technical issues were rarely debated openly and even problems that stemmed from organizational and technical shortcomings were automatically interpreted as political attempts to sabotage or manipulate the process. Nevertheless, even in a climate of heightened political controversy, evidence suggests that only a minority of Beninese voters followed the appeal of political leaders to boycott voter registration, and even this minority changed their minds at a later stage of the process. This confirms the potential of voter registration to generate compliance from citizens, even in an unfavourable context.

The Beninese case also suggests that donor contributions and new technologies, while greatly facilitating voter registration in the short term, may be inhibiting its long-term potential of triggering a deeper process of state building and the establishment of viable and permanent systems 
of citizen identification. Although important advances in state-building processes in the past have been achieved with the contribution of non-state resources, the situation of protracted donor dependency in which a number of contemporary African countries, including Benin, find themselves is to some extent exceptional in history. This situation results in donors promoting state building 'from the outside', assuming the driving role which is in theory reserved for the government. In the case of the LEPI project, it can be argued that donors' actions have in some ways been unsustainable and selective. While choosing to fund voter registration processes, donors should consider not only the potential for making the electoral process less vulnerable to fraud in the short term, but should also take into account additional issues, such as the sustainability of the registration systems employed and the effect on long-term state capacity.

\section{APPENDIX}

[insert Table A1 here. Title of Table should read:

Table A1. Coverage of Civil Registration Systems, Sub-Saharan Africa ] 


\section{REFERENCES}

For non-English titles, we ask for translations into English (which will appear alongside the original). This applies to articles, chapters, papers, books, but not to journal titles. I have highlighted the author names in yellow.

Allen, C. (1992) 'Restructuring an Authoritarian State: “Democratic Renewal” in Benin', Review of African Political Economy 19(54): 42-58.

Assoukpe, K. (2011) 'Projet d'Appui à la Réalisation de la LEPI: Rapport d'Execution (20082011)'. Project Report. Cotonou: United Nations Development Programme. [LEPI Implementation Support Project: Execution Report]

Bako-Arifari, N. (2001) 'La corruption au port de Cotonou: douaniers et intermédiaires', Politique africaine (3): 38-58 [Corruption at the Port of Cotonou: custom officers and middlemen].

Banégas, R. (2003) La démocratie à pas de caméléon: Transition et imaginaires politiques au Bénin. Paris: Karthala [Democracy at chameleon's pace. Transition and political imagination in Benin].

Banégas, R. (2014) 'Briefing: Benin: Challenges for Democracy’, African Affairs 452(113): 449459.

Bayart, J.F. (2000) 'Africa in the World: A History of Extraversion', African Affairs 99(395): 21767.

Bierschenk, T. (2009) 'Democratization without Development: Benin 1989-2009', International Journal of Politics, Culture, and Society 22(3): 337-57.

Bleck, J. and N. van de Walle (2011) 'Parties and Issues in Francophone West Africa: Towards a Theory of Non-mobilization', Democratization 18(5): 1125-45.

Blundo, G. and J.P. Olivier de Sardan (2006). Everyday Corruption and the State. Citizens and Public Officials in Africa. London: Zed Books.

Bratton, M. and E.C.C. Chang (2006) 'State Building and Democratization in Sub-Saharan Africa', Comparative Political Studies 39(9): 1059-83.

Bratton, M. and N. van de Walle (1997) Democratic Experiments in Africa: Regime Transitions in Comparative Perspective. Cambridge: Cambridge University Press.

Breckenridge, K. (2010) 'The World's First Biometric Money: Ghana's e-Zwich and the Contemporary Influence of South African Biometrics', Africa 80(4): 642-62.

Breckenridge, K. and S. Szreter (2012) Registration and Recognition: Documenting the Person in World History. Oxford: Oxford University Press and British Academy. 
Carbone, G. (2013) 'Democratisation as a State-Building Mechanism: A Preliminary Discussion of an Understudied Relationship', Political Studies Review (published online 9 May 2013). DOI: 10.1111/1478-9302.12020.

Chabal, P. and J.P. Daloz (1999) Africa Works: Disorder as Political Instrument. Oxford: James Currey.

Conseil d'Orientation et de Supervision de la Liste Electorale Permanente Informatisée (COS-

LEPI) (2014) official facebook page $<$ https://www.facebook.com/pages/Cos-Lepi-

Benin/537836422921496> (accessed 5 April 2014).

Cooper, F. (2002) Africa since 1940: The Past of the Present. Cambridge: Cambridge University Press.

Cooper, F. (2012) 'Voting, Welfare and Registration: The Strange Fate of the Etat-Civil in French

Africa, 1945-1960', in K. Breckenridge and S. Szreter (eds) Registration and Recognition:

Documenting the Person in World History, pp. 385-412. Oxford: Oxford University Press and British Academy.

Devarajan, S. (2013) 'Africa's Statistical Tragedy', Review of Income and Wealth 59(S1): 9-15.

Diamant, N.J. (2001) 'Making Love "Legible" in China: Politics and Society during the

Enforcement of Civil Marriage Registration, 1950-66', Politics \& Society 29(3): 447-80.

Englebert, P. (2000) State Legitimacy and Development in Africa. Boulder, CO: Lynne Rienner.

Evrensel, A. (2010) Voter Registration in Africa: A Comparative Analysis. Johannesburg: Electoral Institute for the Sustainability of Democracy in Africa (EISA).

Fetter, B. (1987) 'Decoding and Interpreting African Census Data: Vital Evidence from an Unsavory Witness', Cahiers d'Etudes africaines 27(105-106): 83-105.

Gelb, A. and J. Clark (2013) 'Identification for Development: The Biometrics Revolution'. Center for Global Development Working Paper 315. New York: Center for Global Development. Gelb, A. and C. Decker (2012) 'Cash at Your Fingertips: Biometric Technology for Transfers in Developing Countries', Review of Policy Research 29(1): 91-117.

Gisselquist, R.M. (2008) 'Democratic Transition and Democratic Survival in Benin', Democratization 15(4): 789-814.

Heilbrunn, J.R. (1993) 'Social Origins of National Conferences in Benin and Togo', The Journal of Modern African Studies 31(2): 277-99.

Herbst, J.I. (2000) States and Power in Africa: Comparative Lessons in Authority and Control. Princeton, NJ: Princeton University Press.

Huntington, S.P. (2006) Political Order in Changing Societies. New Haven, CT: Yale University Press. 
Igue, O.J. and B.G. Soulé (1992) L'État entrepôt au Bénin: commerce informel ou solution à la crise? Paris: Karthala [The storehouse state in Benin: informal trade or solution to the crisis?]. INSAE (2002) 'Benin 2001'. Demographic and Health Survey. Cotonou: Institut National de la Statistique et de l'Analyse Économique.

http://www.measuredhs.com/Publications/Publication-

Search.cfm?ctry_id=52\&country=Benin (accessed 6 September 2013).

INSAE (2007) 'Benin 2006'. Demographic and Health Survey. Cotonou: Institut National de la

Statistique et de l'Analyse Économique.

http://www.measuredhs.com/Publications/Publication-

Search.cfm?ctry id=52\&country=Benin (accessed 6 September 2013).

Jerven, M. (2013) Poor Numbers: How We Are Misled by African Development Statistics and What to do About it. Ithaca, NY: Cornell University Press.

Lindberg, S.I. (2003) “'It’s Our Time to Chop”: Do Elections in Africa Feed Neo-Patrimonialism rather than Counteract It?', Democratization 10(2): 121-40.

Loveman, M. (2005) 'The Modern State and the Primitive Accumulation of Symbolic Power', American Journal of Sociology 110(6): 1651-83.

Lucas, J. (1998) 'The Tension between Despotic and Infrastructural Power: The Military and the Political Class in Nigeria, 1985-1993', Studies in Comparative International Development 33(3): 90-113.

Mann, M. (1984) 'The Autonomous Power of the State: Its Origins, Mechanisms and Results', European Journal of Sociology 25(2): 185-213.

Mann, M. (2008) 'Infrastructural Power Revisited', Studies in Contemporary International Development 43(3-4):355-65.

Mansfield, E.D. and J. Snyder (1995) 'Democratization and the Danger of War', International Security 20(1): 5-38.

Moss, T., G. Pettersson and N. van de Walle (2006) 'An Aid-institutions Paradox? A Review Essay on Aid Dependency and State Building in Sub-Saharan Africa'. Center for Global Development Working Paper no. 74. New York: Center for Global Development.

Olihide, C. and O. Alladatin (2012) 'La Liste Electorale Permanente Informatisée (LEPI). Etat des lieux et modalités de correction'. Bulletin de Cotonou no. 2. Cotonou: Friedrich Ebert Stiftung [The Permanent Electronic Electoral List. Current assessment and correction options].

Olivier de Sardan, J.P. (2004) 'État, bureaucratie et gouvernance en Afrique de l'Ouest francophone', Politique africaine (4): 139-62 [State, bureaucracy and governance in Frenchspeaking West Africa] 
Paris, R. (2004) At War's End: Building Peace after Civil Conflict. Cambridge and New York: Cambridge University Press.

Pearce, A.J. (2001) 'The Peruvian Population Census of 1725-1740', Latin American Research Review 36(3): 69-104.

Piccolino, G. (2015) 'Infrastructural state capacity for democratization? Voter registration and identification in Côte d'Ivoire and Ghana compared', Democratization, forthcoming..

Ploux, F. (1999) 'Politique, rumeurs et solidarités territoriales dans les résistances au recensement de 1841', Cahiers d'histoire 44(2): 237-66 [Politics, rumours and local solidarities in the resistance to the 1841 census].

Redding, S. (2000) 'A Blood-Stained Tax: Poll Tax and the Bambatha Rebellion in South Africa', African Studies Review 43(2): 29-54

Republic of Benin (2002) 'Loi n. 2002-07 portant code des personnes et de la famille'. Cotonou: National Assembly of Benin, Republic of Benin [Law n. 2002-07 establishing the legal code of the person and the family].

Republic of Benin (2009) 'Loi n. 2009-10 portant organisation du recensement électoral national approfondi et établissement de la Liste Electorale Permanente Informatisée (LEPI)'. Cotonou: National Assembly of Benin, Republic of Benin [Law n. 2009-10 on the organization of the extensive national electoral census and the establishment of the Permanent Electronic Electoral List].

Republic of Benin (2012) 'Loi n. 2012-43 portant apurement, correction, mise à jour et actualisation du fichier électoral national et de la liste électorale permanente informatisée (LEPI)'. Cotonou: National Assembly of Benin, Republic of Benin [Law n. 2012-43 on the auditing, correction and updating of the national voter roll and of the Permanent Electronic Electoral List].

Sangaré, S. (ed.) (2012) 'Mission d'évaluation du contenu de la Liste électorale permanente informatisée du Bénin et des fonctionnalités de son logiciel de gestion'. Report of the independent mission of the Réseau des Compétences Electorales Francophones (RECEF). Cotonou: Organisation Internationale de la Francophonie (OIF) [Assessment mission on the content of the Permanent Electronic Electoral List and its management software].

Scott, J.C. (1999) Seeing Like a State: How Certain Schemes to Improve the Human Condition Have Failed. New Haven, CT: Yale University Press.

Sessou, F., M. Paternotre, F. Bargiacchi and D. Ramazani (2009), 'Etude sur la Liste Electorale Permanente Informatisée (LEPI). Formulation du Projet d'Assistance Electorale'. Expert mission final report, Transtec and European Commission - United Nations Development Programme (EC-UNDP) Partnership on Electoral Assistance. [Report on the Permanent 
Electronic Electoral List. Design of the Electoral Assistance Project] [Where published/available?]

Setel, P.W., S.B. Macfarlane, S. Szreter, L. Mikkelsen, P. Jha, S. Stout and C. Abou Zahr (2007) 'A Scandal of Invisibility: Making Everyone Count by Counting Everyone', The Lancet 370(9598): 1569-77.

Slater, D. (2008) 'Can Leviathan be Democratic? Competitive Elections, Robust Mass Politics, and State Infrastructural Power', Studies in Comparative International Development 43(3-4): 252-72.

van de Walle, N. (2002) 'Elections without Democracy: Africa's Range of Regimes', Journal of Democracy 13(2): 66-80.

Wantchekon, L. (2003) 'Clientelism and Voting Behavior: Evidence from a Field Experiment in Benin', World Politics 55(3): 399-422.

Yard, M. (ed.) (2011) 'Civil and Voter Registries: Lessons Learned from Global Experiences'. Report of the International Foundation for Electoral Systems (IFES). Washington, DC: IFES.

Giulia Piccolino (giulia.piccolino@giga-hamburg.de) is an Alexander Von Humboldt Postdoctoral fellow at the Institute of African Affairs, German Institute of Global and Area Studies (GIGA), Hamburg, Germany. Her current research focuses on civil wars and post-conflict peacebuilding. Having worked in the past in the field of electoral assistance, she is also interested in issues of electoral administration and electoral integrity, particularly in Sub-Saharan Africa. 